\title{
Микология
}

\section{РОСТОВЫЕ И БИОХИМИЧЕСКИЕ ХАРАКТЕРИСТИКИ НЕКОТОРЫХ ВИДОВ СЬЕДОБНЫХ И ЛЕКАРСТВЕННЫХ ГРИБОВ В ЗАВИСИМОСТИ ОТ СПОСОБОВ ПРЕДОБРАБОТКИ ЛИГНОЦЕЛЛЮЛОЗНЫХ СУБСТРАТОВ*}

\author{
А.В. ГОЛЫШКИН, Н.Р. АЛЬМЯШЕВА, М.Ю. ЗИАНГИРОВА, \\ Л.М. КРАСНОПОЛЬСКАЯ
}

Разработка новых эффективных субстратов для культивирования съедобных ксилотрофных грибов актуальна для получения высококачественной пищевой продукции и рационального использования природных ресурсов. В процессе химической предобработки лигноцеллюлозного сырья происходит модификация его химического состава и удаление ингибирующих рост компонентов, что влияет на физиологические и биохимические процессы у грибов. Цель настоящей работы состояла в установлении влияния способов предобработки лиственных и хвойных опилок на ростовые и биохимические характеристики лекарственного базидиомицета Ganoderma lucidum (Curtis) P. Karst. и съедобных базидиомицетов Flammulina velutipes (Curtis) Singer и Hericium erinaceus (Bull.) Persoon, также обладающих лекарственными свойствами. Использовали измельченные опилки сосны (Pinus sylvestris L.) и бука (Fagus orientalis Lipsky) с размером частиц 0,24-0,315 мм. Лигноцеллюлозное сырье обрабатывали $2 \%$ растворами соляной кислоты, серной кислоты, гидроксида натрия и пероксида водорода в автоклаве при $120{ }^{\circ} \mathrm{C}$ в течение 60 мин. Предобработка раствором $\mathrm{NaOH}$ привела к статистически достоверному $($ p $<0,05)$ увеличению доли легкогидролизуемых углеводов на 7 \% для опилок сосны и на 4 \% - для опилок бука по сравнением с контролем. Кислотная предобработка, напротив, способствовала увеличению доли трудногидролизуемых соединений в сырье на $20 \%$. $\mathrm{H}_{2} \mathrm{O}_{2}$ не оказала существенного влияния на содержание легкогидролизуемых углеводов в опилках бука и сосны. Химически предобработанные опилки сосны и бука были использованы в качестве основы субстратов для культивирования ксилотрофных базидиомицетов. Помимо опилок, субстраты содержали $10 \%$ пшеничных отрубей и 1 \% $\mathrm{CaCO}_{3}$. Щелочная и кислотная предобработки способствовали увеличению биодоступности лигноцеллюлозного сырья для вегетативного роста G. lucidum. Повышение скорости роста и плотности мицелия $\boldsymbol{F}$. velutipes и $\boldsymbol{H}$. erinaceus отмечалось только после кислотных предобработок опилок. Предобработка опилок сосны $\mathrm{HCl}$ способствовала увеличению диаметров колоний $F$. velutipes и $H$. erinaceus с $51 \pm 1$ и $19 \pm 2$ мм до $62 \pm 1$ и $23 \pm 4$ мм, опилок бука с $48 \pm 4$ и $19 \pm 2$ мм до $50 \pm 4$ и $32 \pm 3$ мм. На субстрате, содержащем сосновые опилки после щелочной предобработки, роста $H$. erinaceus не было. На субстратах, содержащих предобработанные кислотами опилки бука или сосны, получили плодовые тела $\boldsymbol{H}$. erinaceus и определили содержание в них белков и полисахаридов. Кислотная предобработка опилок сосны и бука привела к 2-кратному ускорению процесса плодоношения. Вторую волну плодоношения H. erinaceus получили только на субстрате с опилками, обработанными НCl. Суммарная урожайность плодовых тел первой и второй волны на субстрате с предобработанными сосновыми опилками составила $8,0 \%$ в пересчете на сухое вещество, в контроле $-3,9$ \%. Плодовые тела второй волны, полученные на субстрате с опилками после солянокислотной предобработки, содержали в 1,3 раза больше белков и в 1,7 раз меныше полисахаридов, чем плодовыме тела первойволны. Таким образом, кислотная предобработка снижала долю легкогидролизуемых углеводов в составе опилок сосны и бука, щелочная предобработка способствовала частичному удалению лигнина и тем самым повышала долю общих углеводов. Все виды химической предобработки приводили к увеличению скорости роста и плотности мицелия $G$. lucidum. В случае $\boldsymbol{F}$. velutipes и $\boldsymbol{H}$. erinaceus отмечали бо́лышую биодоступность опилок после кислотных предобработок. Показано достоверное увеличение урожайности $H$. erinaceus по сравнению с контролем на субстратах, содержащих опилки сосны после солянокислотной предобработки.

Ключевые слова: базидиомицеты, Hericium erinaceus, Ganoderma lucidum, Flammulina velutipes, твердофазное культивирование, субстрат, сосновые опилки, буковые опилки, предобработка.

Вовлечение в технологические процессы трудноперерабатываемых отходов сельского хозяйства, пищевой и лесоперерабатывающей промышленности - ключевой аспект рационального использования природных ресурсов $(1,2)$. Опилки хвойных пород деревьев, листва, хвоя, кора представляют собой ценное сырье для включения в существующие производ-

* Работа выполнена при финансовой поддержке РФФИ, проект № 16-38-00902 мол_а. 
ственные циклы $(3,4)$. Однако эти отходы, помимо целлюлозы, гемицеллюлоз и лигнина, содержат полифенольные и дубильные соединения, отрицательно влияющие на переработку сырья $(5,6)$. Нежелательные компоненты могут быть удалены в процессе предобработки с помощью физических $(7)$, химических $(8,9)$ или биологических методов $(10)$. В результате увеличивается реакционная способность ключевых компонентов за счет разрыва межмолекулярных связей, уменьшения степени кристалличности, увеличение размера пор и площади доступной поверхности сырья (11-13). Успешным примером внедрения новых технологий, включающих этап предобработки лигноцеллюлозного сырья, служит получение этанола (14-16). Выход спирта при использовании предобработанного аммиаком жома сахарного тростника в 6 раз выше по сравнению с непредобработанным (17).

При получении плодовых тел съедобных ксилотрофных грибов находят применение опилки лиственных пород деревьев, солома, лузга подсолнечника и кукурузные кочерыжки, не требующие модификации химического состава $(18,19)$. Можно предположить, что предобработка этих субстратов будет способствовать повышению их биодоступности. Использование непредобработанных опилок хвойных пород для производства плодовых тел нецелесообразно, поскольку смолы в составе древесины подавляют рост грибов и ухудшают качество получаемой продукции.

В научной литературе отсутствуют сведения о сравнении различных видов химической предобработки лигноцеллюлозного сырья при разработке эффективных субстратов для получения плодовых тел грибов.

В настоящей работе впервые проведена оценка ростовых и биохимических характеристик ксилотрофных грибов при выращивании на субстратах, содержащих химически предобработанное лигноцеллюлозное сырье. Показано, что доля углеводов в составе опилок снижалась при кислотной предобработке и повышалась при щелочной. Рост и плотность мицелия Ganoderma lucidum (Curtis) P. Karst. увеличивались после всех видов предобработки. Для Flammulina velutipes (Curtis) Singer и Hericium erinaceus (Bull.) Persoon более доступны оказались субстраты после кислотных предобработок. Предобработка опилок сосны и бука соляной кислотой, а также опилок сосны серной кислотой обеспечивала вторую волну плодоношения у H. erinaceus. При этом плодовые тела первой и второй волн значительно различались по содержанию белков и полисахаридов.

Цель работы состояла в установлении влияния способов предобработки лиственных и хвойных опилок на ростовые и биохимические характеристики некоторых видов съедобных и лекарственных грибов.

Mетодика. Опилки сосны (Pinus sylvestris L.) и бука (Fagus orientalis Lipsky) измельчали до частиц размером 0,24-0,315 мм и высушивали при температуре $60{ }^{\circ} \mathrm{C}$ в течение 48 ч. В колбах Эрленмейера (объем 750 мл) 100 г высушенных опилок смешивали с $2 \%$ растворами соляной кислоты, серной кислоты, гидроксида натрия и пероксида водорода (все реактивы ООО «Русхим», Россия) в соотношении 1:1. Колбы выдерживали в автоклаве (стерилизатор паровой ВК-75-01, АО «ТЗМОИ», Россия) при $120{ }^{\circ} \mathrm{C}$ в течение 60 мин. Предобработанные опилки отделяли фильтрованием через обеззоленные бумажные фильтры под вакуумом, промывали дистиллированной водой до рН 7 и высушивали при $60{ }^{\circ} \mathrm{C}$ в течение 48 ч.

В конических колбах (объем 100 мл) 1 г высушенных предобработанных опилок смешивали с 45 мл 1,5\% раствора соляной кислоты. Колбы выдерживали в автоклаве при $120^{\circ} \mathrm{C}$ в течение 120 мин. Реакционную смесь воздушно охлаждали до комнатной температуры в течение 30 мин и фильтровали через обеззоленные бумажные фильтры под вакуумом. Долю легкогидролизуемых углеводов в предобработанных опилках определяли, 
измеряя количество редуцирующих веществ (РВ) в фильтратах гидролизатов стандартным спектрофотометрическим методом с использованием 3,5динитросалициловой кислоты («Acros Organics B.V.B.A.», Бельгия) (20).

Штаммы лекарственного базидиомицета G. lucidum и съедобных базидиомицетов $F$. velutipes и $H$. erinaceus, также обладающих лекарственными свойствами, получены из коллекции НИИ по изысканию новых антибиотиков им. Г.Ф. Гаузе. Рабочие культуры хранили на скошенном картофельно-глюкозном агаре при $4{ }^{\circ} \mathrm{C}$.

В чашки Петри помещали твердый субстрат, содержащий 4,5 г опилок, 0,5 г пшеничных отрубей, 0,05 г $\mathrm{CaCO}_{3}$ (OOO «Русхим», Россия) и добавляли 8 мл горячей $\left(90^{\circ} \mathrm{C}\right)$ дистиллированной воды, $\mathrm{pH}$ субстратов доводили до $6,0 \pm 0,2$. Чашки Петри стерилизовали при $120^{\circ} \mathrm{C}$ в течение 1 ч, засевали мицелиально-агаровыми блоками 10-суточных культур грибов (диаметр 3 мм) и инкубировали при $25^{\circ} \mathrm{C}$ в течение 9 сут, после чего измеряли диаметр колоний.

Для получения плодовых тел $H$. erinaceus в конические плоскодонные колбы (объем 200 мл) помещали твердый субстрат, содержащий 18 г опилок, 2 г пшеничных отрубей, 0,2 г $\mathrm{CaCO}_{3}$ и добавляли 32 мл горячей $\left(90{ }^{\circ} \mathrm{C}\right)$ дистиллированной воды, $\mathrm{pH}$ субстратов доводили до $6,0 \pm 0,2$. Для оценки влияния предобработки опилок на урожайность и биохимический состав плодовых тел содержание обязательного дополнительного источника азота (отруби) составляло половину от нормы по общепринятым рекомендациям (21). Колбы стерилизовали при $120^{\circ} \mathrm{C}$ в течение 60 мин, засевали мицелиально-агаровыми блоками 10-суточной культуры $H$. erinaceus (диаметр 3 мм) и инкубировали в темноте при $25^{\circ} \mathrm{C}$ в течение 3 нед до полного зарастания субстрата мицелием. После этого удаляли ватно-марлевые пробки и инкубировали колбы при $20^{\circ} \mathrm{C}$, относительной влажности воздуха $80 \%$ в течение 3 мес. В инкубационной камере поддерживали воздухообмен 0,1 об/мин и 8-часовой световой день при освещенности 150 лк с использованием диодных ламп. Плодовые тела снимали по достижении ими товарной зрелости, высушивали (лиофильная сушилка ЛС-500, ООО «Проинтех», Россия), измельчали и анализировали.

Общее содержание полисахаридов определяли фенолсернокислотным методом с использованием глюкозы (ООО «НТК ДИАЭМ», Россия) в качестве стандарта (22). Белки экстрагировали 0,1 М фосфатным буфером $(\mathrm{pH} 7,4)$ в течение 3 ч при постоянном перемешивании. Общее содержание белков оценивали методом М.M. Bradford (23), стандарт - бычий сывороточный альбумин (ООО «НТК ДИАЭМ», Россия).

Все эксперименты проводили в 3 биологических и 3 аналитических повторностях.

Статистическую обработку результатов осуществляли с помощью пакета программ Microsoft Excel 2013. На рисунках и в таблицах представлены средние значения $(M)$ и стандартные ошибки средних $( \pm \mathrm{SEM})$. Достоверность различий между средними значениями исследуемых показателей оценивали по $t$-критерию Стьюдента, статистически значимыми считали различия при $\mathrm{p} \leq 0,05$.

Результаты. Выбор объектов был обусловлен их хозяйственной ценностью, поскольку эти виды служат продуцентами питательных и биологически активных соединений (24-28).

Доля легкогидролизуемых углеводов в необработанных опилках сосны составила $30 \%$, бука - 37 \% (рис. 1), что соответствует количеству гемицеллюлоз в сырье (29). Предобработка раствором гидроксида натрия способствовала увеличению доли легкогидролизуемых углеводов на $7 \%$ 


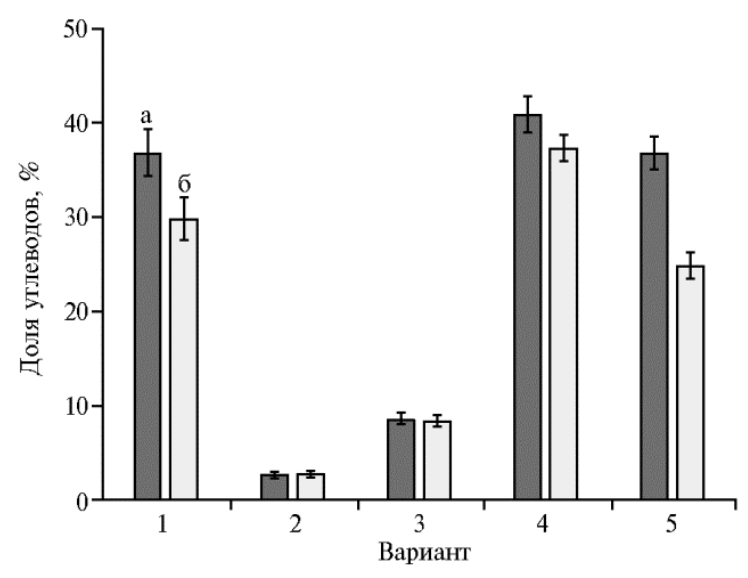

Рис. 1. Доля легкогидролизуемых углеводов в опилках бука (Fagus orientalis) (а) и сосны (Pinus sylvestris) (б) до и после химических предобработок: 1 - контроль, $2-2 \%$ соляная кислота, $3-2 \%$ серная кислота, $4-$ $2 \%$ гидроксид натрия, $5-2 \%$ пероксид водорода.

Скорее всего, это было следствием удаления лигнина и части гемицеллюлоз, что согласуется с данными литературы (30). Пероксид водорода не оказал достоверного влияния на содержание легкогидролизуемых углеводов в опилках бука. Предобработка опилок сосны приводила к снижению их доли на $5 \%$. Возможно, различия в результатах предобработки пероксидом водорода связаны с различием в химической структуре гемицеллюлоз и лигнина хвойных и лиственных пород деревьев (31).

Кислотная предобработка вызывала резкое увеличение доли трудногидролизуемых соединений в сырье: содержание легкогидролизуемых углеводов в опилках сосны и бука снизилось на $20 \%$ (p $\leq 0,05)$. Поскольку убыль массы субстрата превосходила долю легкогидролизуемых сахаров, в результате кислотной предобработки наблюдался не только гидролиз гемицеллюлоз и аморфных участков целлюлозы, но также частично был удален лигнин. Аналогичный результат химических изменений под воздействием минеральных кислот был получен при изучении предобработки древесины тополя (32).

На следующем этапе мы оценили влияние предобработки на биодоступность субстратов для ксилотрофных базидиомицетов, вызывающих белую гниль, то есть способных утилизировать лигнин. Определяли скорость освоения субстрата и интенсивность развития мицелия (табл. 1).

1. Диаметр 8-суточных колоний (d) и визуальная оценка плотности мищелия (q) ксилотрофных базидиомицетов при выращивании в чашках Петри в зависимости от химической предобработки субстрата ( $M \pm \mathrm{SEM})$

\begin{tabular}{|c|c|c|c|c|c|c|c|}
\hline \multirow{2}{*}{ Субстрат } & \multirow{2}{*}{ Предобработка } & \multicolumn{2}{|c|}{ Ganoderma lucidum } & \multicolumn{2}{|c|}{ Flammulina velutipes } & \multicolumn{2}{|c|}{ Hericium erinaceus } \\
\hline & & $\mathrm{d}, \mathrm{MM}$ & $\mathrm{q}$ & $\mathrm{d}, \mathrm{MM}$ & $\mathrm{q}$ & $\mathrm{d}, \mathrm{MM}$ & $\mathrm{q}$ \\
\hline \multirow[t]{5}{*}{ Сосна } & Контроль & $43 \pm 4$ & 2 & $51 \pm 1$ & 2 & $19 \pm 2$ & 2 \\
\hline & $\mathrm{HCl}, 2 \%$ & $58 \pm 7$ & 3 & $62 \pm 1$ & 2 & $23 \pm 4$ & 2 \\
\hline & $\mathrm{H}_{2} \mathrm{SO}_{4}, 2 \%$ & $52 \pm 3$ & 3 & $62 \pm 2$ & 2 & $29 \pm 2$ & 2 \\
\hline & $\mathrm{NaOH}, 2 \%$ & $63 \pm 4$ & 3 & $58 \pm 2$ & 1 & - & - \\
\hline & $\mathrm{H}_{2} \mathrm{O}_{2}, 2 \%$ & $49 \pm 7$ & 3 & $54 \pm 1$ & 1 & $24 \pm 2$ & 1 \\
\hline \multirow[t]{5}{*}{ Бук } & Контроль & $34 \pm 1$ & 2 & $48 \pm 4$ & 3 & $19 \pm 2$ & 2 \\
\hline & $\mathrm{HCl}, 2 \%$ & $49 \pm 6$ & 3 & $50 \pm 4$ & 3 & $32 \pm 3$ & 2 \\
\hline & $\mathrm{H}_{2} \mathrm{SO}_{4}, 2 \%$ & $38 \pm 3$ & 3 & $57 \pm 2$ & 3 & $32 \pm 3$ & 2 \\
\hline & $\mathrm{NaOH}, 2 \%$ & $60 \pm 8$ & 3 & $63 \pm 4$ & 1 & $24 \pm 1$ & 1 \\
\hline & $\mathrm{H}_{2} \mathrm{O}_{2} 2 \%$ & $49 \pm 7$ & 3 & $42 \pm 5$ & 1 & $26 \pm 2$ & 1 \\
\hline
\end{tabular}

Все виды химической предобработки способствовали увеличению скорости роста и плотности мицелия G. lucidum. То есть G. lucidum с одинаковой эффективностью усваивал субстраты, обогащенные как лигнином (кислотная предобработка), так и углеводами (щелочная и перекисная предобработка). Повышение биодоступности субстратов, содержащих предобработанные опилки, для G. lucidum, вероятно, связано с разрушением межмолекулярных связей лигноцеллюлозного комплекса в результате хи- 
мического воздействия. Для $F$. velutipes и $H$. erinaceus более доступны были субстраты после кислотных предобработок. При этом обогащение субстратов лигнином привело к увеличению скорости роста базидиомицетов на опилках как сосны, так и бука по сравнению с контролем. Перекисная и щелочная предобработки не способствовали повышению биодоступности субстратов для $F$. velutipes и $H$. erinaceus. При незначительном повышении скорости роста $F$. velutipes на обогащенных углеводами опилках плотность мицелия снизилась. Рост H. erinaceus на субстрате, содержащем сосновые опилки после щелочной предобработки, отсутствовал.

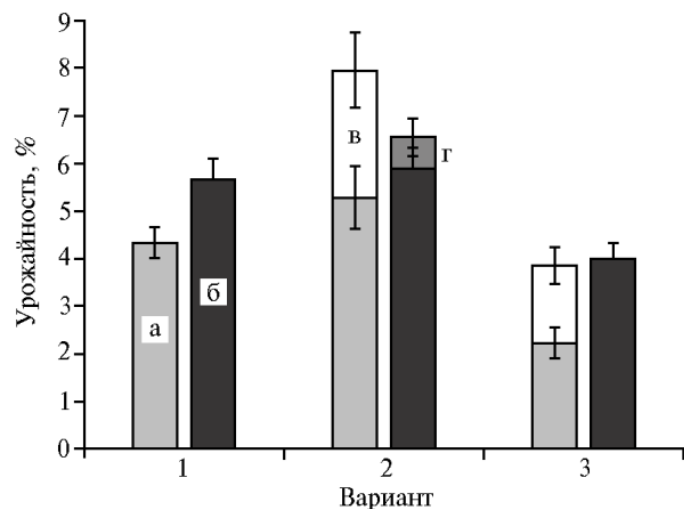

Рис. 2. Урожайность плодовых тел Hericium erinaceus в контроле (1), на субстратах, предобработанных $2 \%$ соляной (2) и серной (3) кислотой в пересчете на сухое вещество: а - сосна, первая волна; б - бук, первая волна; в - сосна, вторая волна; г - бук, вторая волна.

Анализ данных литературы показывает, что наибольшее количество технологий разработано для культивирования $G$. $l u$ cidum и $F$. velutipes (18). В то же время съедобный гриб $H$. erinaceus, обладающий лекарственными свойствами, представляет собой ценный продукт питания и источник биологически активных веществ, таких как иммуномодулирующие и противоопухолевые полисахариды, антиоксиданты, нейроактивные соединения $(24,26,33)$.

На непредобработанных опилках сосны и бука за все время эксперимента нами была получена только одна волна плодовых тел $H$. erinaceus, которые достигли товарной зрелости через 63 сут культивирования (табл. 2). Кислотная предобработка привела к значительному ускорению процесса плодоношения H. erinaceus. За 2 мес эксперимента на субстратах, содержащих все варианты предобработанных опилок, за исключением опилок бука после сернокислотной предобработки, были получены две волны плодоношения. Плодовые тела 1-й и 2-й волн были сняты по достижении ими товарной зрелости соответственно на 35-е и 63-е сут. Повышение урожайности по сравнению с контролем отмечали на опилках сосны, предобработанных соляной кислотой $(\mathrm{p} \leq 0,05)$ (рис. 2, 3).

A

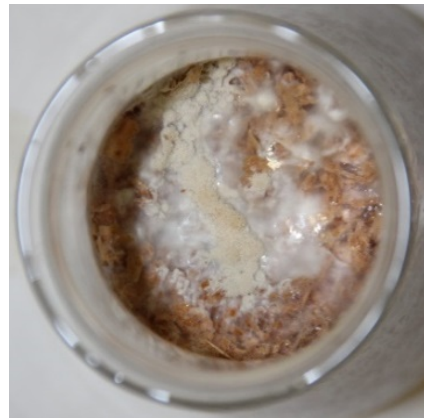

Б

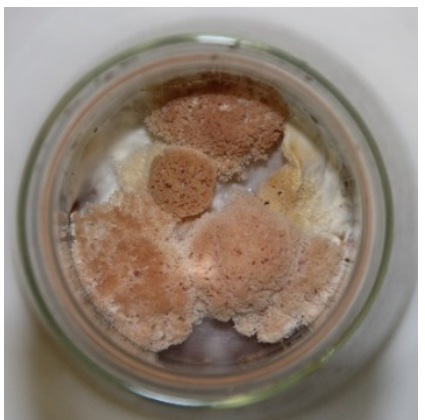

B

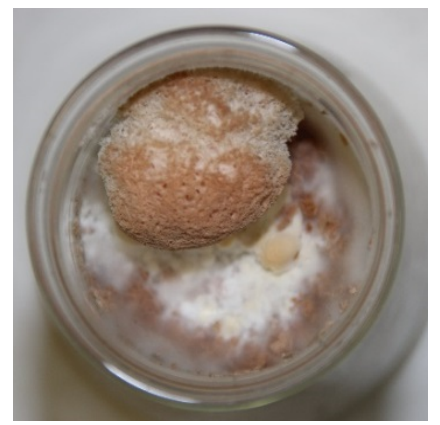

Рис. 3. Внешний вид Hericium erinaceus на 35-е сут культивирования при разных способах химической предобработки субстрата: А - вегетативный мицелий на непредобработанных опилках сосны, Б - плодовые тела на опилках сосны после солянокислотной предобработки, В плодовые тела на опилках сосны после сернокислотной предобработки. 
Возможно, это связано с тем, что хлорид-анионы способны разрушать межмолекулярные водородные связи лигноцеллюлозного комплекса и увеличивать биодоступность лигнина (34). Несмотря на то, что при сернокислотной предобработке сосновых опилок было получено две волны плодоношения, суммарная урожайность оказалась сопоставима с урожайностью первой волны на субстрате без предобработки.

2. Плодоношение Hericium erinaceus в зависимости от химической предобработки древесных субстратов

\begin{tabular}{|c|c|c|c|}
\hline \multirow{2}{*}{ Субстрат } & \multirow{2}{*}{ Предобработка } & \multicolumn{2}{|c|}{ Срок достижения товарной зрелости, сут } \\
\hline & & первая волна & вторая волна \\
\hline \multirow[t]{3}{*}{ Сосна } & Контроль & 63 & - \\
\hline & $\mathrm{HCl}, 2 \%$ & 35 & 63 \\
\hline & $\mathrm{H}_{2} \mathrm{SO}_{4}, 2 \%$ & 35 & 63 \\
\hline \multirow[t]{3}{*}{ Бук } & Контроль & 63 & - \\
\hline & $\mathrm{HCl} 2, \%$ & 35 & 63 \\
\hline & $\mathrm{H}_{2} \mathrm{SO}_{4}, 2 \%$ & 35 & - \\
\hline
\end{tabular}

Пр и м е ч н и е. Товарная зрелость - стадия развития плодовых тел, при которой осуществляется их сбор для реализации. Прочерки означают отсутствие плодоношения.

3. Содержание белков и полисахаридов в плодовых телах Hericium erinaceus в зависимости от химической предобработки древесных субстратов $(M \pm \mathrm{SEM})$

\begin{tabular}{|c|c|c|c|c|c|}
\hline \multirow{2}{*}{ Субстрат } & \multirow{2}{*}{ Предобработка } & \multicolumn{2}{|c|}{ Первая волна } & \multicolumn{2}{|c|}{ Вторая волна } \\
\hline & & белки, \% & полисахариды, \% & белки, \% & полисахариды, \% \\
\hline \multirow[t]{3}{*}{ Сосна } & Контроль & $12,7 \pm 0,4$ & $41,6 \pm 3,9$ & - & - \\
\hline & $\mathrm{HCl}, 2 \%$ & $12,0 \pm 2,2$ & $42,5 \pm 5,3$ & $16,0 \pm 2,5$ & $24,3 \pm 1,6$ \\
\hline & $\mathrm{H}_{2} \mathrm{SO}_{4}, 2 \%$ & $9,7 \pm 3,9$ & $23,9 \pm 3,4$ & $16,4 \pm 0,5$ & $16,0 \pm 1,3$ \\
\hline \multirow[t]{3}{*}{ Бук } & Контроль & $13,5 \pm 0,5$ & $35,4 \pm 0,9$ & - & - \\
\hline & $\mathrm{HCl}, 2 \%$ & $6,8 \pm 1,2$ & $43,6 \pm 2,3$ & $12,7 \pm 1,7$ & $29,7 \pm 1,9$ \\
\hline & $\mathrm{H}_{2} \mathrm{SO}_{4}, 2 \%$ & $12,4 \pm 0,6$ & $29,4 \pm 0,1$ & - & - \\
\hline рим е & и е. Прочерки & ают отсут & е плодоношения. & & \\
\hline
\end{tabular}

На заключительном этапе мы сравнили содержания белков и полисахаридов в полученных плодовых телах $H$. erinaceus. Сернокислотная предобработка сосновых опилок приводила к снижению массовой доли белков с 13,5 до 6,8 \%, полисахаридов - с 41,6 до 23,9 \% в плодовых телах первой волны (табл. 3). На предобработанных соляной кислотой и непредобработанных опилках сосны получили плодовые тела с достоверно одинаковым содержанием белков и полисахаридов (p > 0,05). Солянокислотная предобработка опилок бука привела к снижению содержания белков в плодовых телах почти в 2 раза по сравнению с контролем, однако на этом субстрате отмечалось максимальное содержание полисахаридов. Установлено, что плодовые тела второй волны отличались от базидиом первой волны более высоким содержанием белков. Подобная закономерность не описана в литературе и требует дальнейшего изучения.

Наши результаты показали, что для разработки составов новых субстратов для твердофазного культивирования и получения плодовых тел $H$. erinaceus наиболее эффективна солянокислотная предобработка сырья, которая позволяет повысить урожайность, ускорить процесс получения базидиом и использовать при культивировании H. erinaceus опилки сосны. Дальнейшие эксперименты будут направлены на изучение влияния солянокислотной предобработки опилок других хвойных пород на рост и плодоношение $H$. erinaceus. Предобработка опилок лиственных пород не целесообразна, поскольку не приводит к повышению биотехнологических и биохимических показателей.

Таким образом, кислотная предобработка снижала долю легкогидролизуемых углеводов в составе опилок сосны и бука. Щелочная предобработка способствовала частичному удалению лигнина и тем самым по- 
вышала долю общих углеводов. Все виды химической предобработки приводили к увеличению скорости роста и плотности мицелия Ganoderma lucidum. Биодоступность опилок для Flammulina velutipes и Hericium erinaceus была выше после кислотных предобработок. При этом наибольшую скорость роста и плотность мицелия отмечали на субстратах с опилками после солянокислотной предобработки. Кислотная предобработка приводила к сокращению времени выхода на плодоношение у H. erinaceus с 63 до 35 сут по сравнению с таковым при применении непредобработанных опилок. Наблюдалось достоверное увеличение $(\mathrm{p} \leq 0,05)$ урожайности $H$. erinaceus на субстратах, содержащих опилки сосны после солянокислотной предобработки. Снижение урожайности отмечено на субстрате, содержащем опилки бука, предобработанные серной кислотой. Плодовые тела второй волны отличались от плодовых тел первой волны повышенным содержанием белков и пониженным - полисахаридов.

\section{ЛИТЕРАТ У РА}

1. Ingrao C., Bacenetti J., Bezama A., Blok V., Geldermann J., Goglio P., Koukios E., Lindner M., Nemecek M., Siracusa V., Zabaniotou A., Huisingh D. Agricultural and forest biomass for food, materials and energy: bio-economy as the cornerstone to cleaner production and more sustainable consumption patterns for accelerating the transition towards equitable, sustainable, post fossil-carbon societies. Journal of Cleaner Production, 2016, 117: 4-6 (doi: 10.1016/j.jclepro.2015.12.066).

2. Gokhberg L., Kuzminov I., Chulok A., Thurner T. The future of Russia's agriculture and food industry between global opportunities and technological restrictions. International Journal of Agricultural Sustainability, 2017, 5(4): 457-466 (doi: 10.1080/14735903.2017.1335572).

3. Grebner D.L., Grala R.K., Joshi O., Perez-Verdin G. Physical and economic aspects to assessing woody biomass availability for bioenergy production and related supply constraints. In: Handbook of bioenergy /S. Eksioglu, S. Rebennack, P. Pardalos (eds.). Springer, Cham, 2015: 299-321 (doi: 10.1007/978-3-319-20092-7_13).

4. Latva-Mäenpää H. Bioactive and protective polyphenolics from roots and stumps of conifer trees (Norway spruce and Scots pine). Unigrafia Oy, Helsinki, 2017.

5. Ogawa M., Okimori Y. Pioneering works in biochar research, Japan. Soil Research, 2010, 48(7): 489-500 (doi: 10.1071/SR10006 489-5006).

6. Jylhä P. Harvesting of undelimbed Scots pine (Pinus sylvestris L.) from first thinnings for integrated production of kraft pulp and energy. Dissertationes Forestales 133. Helsinki, 2011 (doi: 10.14214/df.133).

7. Ewanick S.M., Bura R., Saddler J.N. Acid-catalyzed steam pretreatment of lodgepole pine and subsequent enzymatic hydrolysis and fermentation to ethanol. Biotechnology and Bioengineering, 2007, 98(4): 737-746 (doi: 10.1002/bit.21436).

8. Jin S., Zhang G., Zhang P., Li F., Fan S., Li J. Thermo-chemical pretreatment and enzymatic hydrolysis for enhancing saccharification of catalpa sawdust. Bioresource Technology, 2016, 205: 34-39 (doi: 10.1016/j.biortech.2016.01.019).

9. Lai C., Yang B., He J., Huang C., Li X., Song X., Yong Q. Enhanced enzymatic digestibility of mixed wood sawdust by lignin modification with naphthol derivatives during dilute acid pretreatment. Bioresource Technology, 2018, 269: 18-24 (doi: 10.1016/j.biortech.2018.08.086).

10. Cuilty K.R., Ballinas-Casarrubias L., de San Miguel E.R., de Gyves J., Robles-Venzor J.C., González-Sánchez G. Cellulose recovery from Quercus sp. sawdust using Ethanosolv pretreatment. Biomass and Bioenergy, 2018, 111: 114-124 (doi: 10.1016/j.biombioe.2018.02.004).

11. Al'myasheva N.R., Novikov A.A., Kozhevnikova E.Yu., Golyshkin A.V., Barkov A. V., Vinkurov V.A. Ethanol production from lignocellulosic biomass using xylotrophic basidiomycetes. Chemistry and Technology of Fuels and Oils, 2015, 51(5): 516-525 (doi: 10.1007/s10553-0150633-6).

12. Kim T.H., Choi C.H., Oh K.K. Bioconversion of sawdust into ethanol using dilute sulfuric acid-assisted continuous twin screw-driven reactor pretreatment and fed-batch simultaneous saccharification and fermentation. Bioresource Technology, 2013, 130: 306-313 (doi: 10.1016/j.biortech.2012.11.125).

13. Mosier N., Wyman C., Dale B., Elander R., Lee Y.Y., Holtzapple M., Ladisch M. Features of promising technologies for pretreatment of lignocellulosic biomass. Bioresource Technology, 2005, 96(6): 673-686 (doi: 10.1016/j.biortech.2004.06.025).

14. Galbe M., Zacchi G. Pretreatment of lignocellulosic materials for efficient bioethanol produc- 
tion. In: Biofuels. Advances in biochemical engineering/biotechnology, Vol. 108 /L. Olsson (ed.). Springer, Berlin, Heidelberg, 2007: 41-65 (doi: 10.1007/10_2007_070).

15. Sun S., Sun S., Cao X., Sun R. The role of pretreatment in improving the enzymatic hydrolysis of lignocellulosic materials. Bioresource Technology, 2016, 199: 49-58 (doi: 10.1016/j.biortech.2015.08.061).

16. Okamoto K., Uchii A., Kanawaku R., Yanase H. Bioconversion of xylose, hexoses and biomass to ethanol by a new isolate of the white rot basidiomycete Trametes versicolor. SpringerPlus, 2014, 3(1): 121 (doi: 10.1186/2193-1801-3-121).

17. Aita G.A., Salvi D.A., Walker M.S. Enzyme hydrolysis and ethanol fermentation of dilute ammonia pretreated energy cane. Bioresource Technology, 2011, 102(6): 4444-4448 (doi: 10.1016/j.biortech.2010.12.095).

18. Stamets P. Growing gourmet and medicinal mushrooms. Ten Speed Press, California, USA, 2000.

19. Rodriguez Estrada A.E., Royse D.J. Yield, size and bacterial blotch resistance of Pleurotus eryngii grown on cottonseed hulls/oak sawdust supplemented with manganese, copper and whole ground soybean. Bioresource Technology, 2007, 98(10): 1898-1906 (doi: 10.1016/j.biortech.2006.07.027).

20. Miller G.L. Use of dinitrosalicylic acid reagent for determination of reducing sugar. Analytical Chemistry, 1959, 31(3): 426-428 (doi: 10.1021/ac60147a030).

21. Atila F., Tüzel Y., Faz Cano A., Fernandez J.A. Effect of different lignocellulosic wastes on Hericium americanum yield and nutritional characteristics. Science of Food and Agriculture, 2017, 97(2): 606-612 (doi: 10.1002/jsfa.7772).

22. Dubois M., Gilles K.A., Hamilton J.K., Rebers P.A., Smith F. Colorimetric method for determination of sugars and related substances. Analytical Chemistry, 1956, 28(3): 350-356 (doi: 10.1021/ac60111a017).

23. Bradford M.M. A rapid and sensitive method for the quantitation of microgram quantities of protein utilizing the principle of protein-dye binding. Analytical Biochemistry, 1976, 72(1-2): 248-254 (doi: 10.1016/0003-2697(76)90527-3).

24. Автономова А.В., Баканов А.В., Леонтьева М.И., Винокуров В.А., Усов А.И., Краснопольская Л.М. Погруженное культивирование и химический состав мицелия Hericium erinaceus. Антибиотики и химиотерапия, 2012, 57(7-8): 7-11.

25. Автономова А.В., Краснопольская Л.М. Противоопухолевые и иммуномодулирующие свойства трутовика лакированного (Ganoderma lucidum). Микология и фитопатология, 2013, 47(1): 3-11.

26. Альмяшева Н.Р., Ярина М.С., Голышкин А.В., Джавахян Б.Р., Краснопольская Л.М. Антиоксидантные свойства водорастворимых полисахаридов и этанольных экстрактов мицелия ксилотрофных базидиальных грибов. Антибиотики и химиотерапия, 2017, 62(78): 8-12.

27. Краснопольская Л.М., Ярина М.С., Автономова А.В., Усов А.И., Исакова Е.Б., Бухман В.М. Сравнительное изучение противоопухолевой активности полисахаридов из мицелия Ganoderma lucidum в опытах in vivo. Антибиотики и химиотерапия, 2015, 60(11-12): 29-34.

28. Краснопольская Л.М., Шуктуева М.И., Автономова А.В., Ярина М.С., Джавахян Б.Р., Исакова Е.Б., Бухман В.М. Противоопухолевые и антиоксидантные свойства водорастворимых полисахаридов из мицелия базидиального гриба Flammulina velutipes. Aнтибиотики и химиотерапия, 2016, 61(11-12): 16-20.

29. Räisänen T., Athanassiadis D. Basic chemical composition of the biomass components of pine, spruce and birch. BioFuel Region AB, 2013. Режим доступа: http://biofuelregion.se/wpcontent/uploads/2017/01/1_2_IS_2013-01-31_Basic_chemical_composition.pdf. Дата обращения 19.05.2019.

30. Jönsson L. J., Martín C. Pretreatment of lignocellulose: formation of inhibitory by-products and strategies for minimizing their effects. Bioresource Technology, 2016, 199: 103-112 (doi: 10.1016/j.biortech.2015.10.009).

31. McMillan J.D. Pretreatment of lignocellulosic biomass. ACS Symposium Series, 1994, 556(15): 292-324 (doi: 10.1021/bk-1994-0566.ch015).

32. Sun Q., Foston M., Meng X., Sawada D., Pingali S.V., O’Neill H.M., Li H., Wyman C.E., Langan P., Ragauskas A.J., Kumar R. Effect of lignin content on changes occurring in poplar cellulose ultrastructure during dilute acid pretreatment. Biotechnology for Biofuels, 2014, 7(1): 150 (doi: 10.1186/s13068-014-0150-6).

33. Friedman M. Chemistry, nutrition, and health-promoting properties of Hericium erinaceus (Lion's Mane) mushroom fruiting bodies and mycelia and their bioactive compounds. Journal of Agricultural and Food Chemistry, 2015, 63(32): 7108-7123 (doi: 10.1021/acs.jafc.5b02914).

34. Foston M., Ragauskas A. J. Biomass characterization: recent progress in understanding biomass recalcitrance. Industrial Biotechnology, 2012, 8(4): 191-208 (doi: 10.1089/ind.2012.0015).

ФГБНУ НИИ по изысканию новых антибиотиков им. Г.Ф. Гаузе,
Поступила в редакцию

1 ноября 2018 года 


\title{
EFFECT OF PRETREATMENT OF LIGNOCELLULOSIC SUBSTRATES ON PHYSIOLOGICAL AND BIOCHEMICAL CHARACTERISTICS OF SOME SPECIES OF EDIBLE AND MEDICAL MUSHROOMS
}

\author{
A.V. Golyshkin, N.R. Almyasheva, M.Yu. Ziangirova, L.M. Krasnopolskaya
}

Gause Institute of New Antibiotics, 11, ul. Bolshaya Pirogovskaya, Moscow, 119867 Russia, e-mail a.v.golyshkin@gmail.com ( $₫$ corresponding author), almyashevanelya@mail.ru, pchelka_mayya@mail.ru, lkrasnopolskay@yandex.ru ORCID:

Golyshkin A.V. orcid.org/0000-0002-3645-1933

Almyasheva N.R. orcid.org/0000-0001-9575-1701

The authors declare no conflict of interests

Acknowledgements:

Supported financially by Russian Foundation for Basic Research, project No. 16-38-00902 mol_a

Received November 1, 2018

Ziangirova M.Yu. orcid.org/0000-0002-0391-0339

Krasnopolskaya L.M. orcid.org/0000-0002-9063-5928

doi: 10.15389/agrobiology.2019.3.607eng

The development of new effective substrates for mushroom cultivation is relevant not only in order to obtain high-quality food products, but also as a need for rational use of natural resources. Chemical pretreatment can modify the chemical composition of various types of lignocellulosic materials and remove the growth-inhibiting compounds which can affect the physiological and biochemical processes in fungi. The present work provides the first comprehensive assessment of growth and biochemical characteristics of xylotrophic basidiomycetes cultivated on substrates that contain chemical pretreated lignocellulosic materials. Edible mushrooms Hericium erinaceus (Bull.) Persoon and Flammulina velutipes (Curtis) Singer and medicinal mushroom Ganoderma lucidum (Curtis) P. Karst. were selected for study. Pine (Pinus sylvestris L.) and beech (Fagus orientalis Lipsky) sawdust of particle size $0.24-0.315 \mathrm{~mm}$ were used. Pretreatment of lignocellulosic material with $2 \% \mathrm{wt}$. solutions of hydrochloric acid, sulfuric acid, sodium hydroxide and hydrogen peroxide was carried out in autoclave at $120{ }^{\circ} \mathrm{C}$ for $60 \mathrm{~min}$. Sodium hydroxide pretreatment resulted in a statistically significant $(\mathrm{p}<0,05)$ increase in the easily hydrolysable carbohydrates content in pine sawdust by $5 \%$ and in beach sawdust by $4 \%$ compared to control. Acid pretreatment instead led to an increase in hardly hydrolysable carbohydrates content in lignocellulosic materials by $20 \%$. Hydrogen peroxide pretreatment had no significant effect on composition of pine and beech sawdust. Chemically pretreated pine and beach sawdust were used as the basis for substrates for cultivation of xylotrophic basidiomycetes. Substrates, in addition to sawdust, contained $10 \%$ wheat bran and $1 \% \mathrm{CaCO}_{3}$. Alkaline and acid pretreatments contributed to increased bioavailability of lignocellulosic materials for the vegetative growth of $G$. lucidum. The colony of $G$. lucidum after nine days of growth on untreated pine sawdust was $43 \pm 4 \mathrm{~mm}$ in diameter, on hydrochloric acid-, sulfuric acid-, sodium hydroxide- and hydrogen peroxide-pretreated pine sawdust were $58 \pm 7,52 \pm 3,63 \pm 4$ and $49 \pm 7 \mathrm{~mm}$ in diameter, respectively. Acid pretreatments of sawdust improved the growth rate and density of $F$. velutipes and $H$. erinaceus vegetative mycelium. Hydrochloric acid pretreatment of pine sawdust led to an increase in the colony diameters of $F$. velutipes and $H$. erinaceus from $51 \pm 1$ and $19 \pm 2 \mathrm{~mm}$ to $62 \pm 1$ и $23 \pm 4 \mathrm{~mm}$, respectively, of beach sawdust - from $48 \pm 4$ and $19 \pm 2 \mathrm{~mm}$ to $50 \pm 4$ и $32 \pm 3 \mathrm{~mm}$, respectively. No growth of $H$. erinaceus occurred on substrate with alkali-pretreated pine sawdust. Fruit bodies of $H$. erinaceus were harvested from substrates containing acid-pretreated and untreated pine and beach sawdust. Acid pretreatments of pine and beach sawdust decreased the cultivation time twice. The second wave of fructification occurred during the cultivation of $H$. erinaceus only on substrates containing hydrochloric acid-pretreated sawdust. This provided an increase in yield of fruit bodies compared to control. The total yield of fruit bodies of the first and second waves cultivated on substrates with pretreated pine sawdust was $8.0 \%$ dry wt., on substrate with untreated sawdust $3.9 \%$ dry wt. The yield of fruit bodies reduced significantly during cultivation of $H$. erinaceus on a substrate with beech sawdust after sulfuric acid pretreatment. For the first time, a significant difference in the protein and polysaccharide contents of fruit bodies of the first and second waves is shown. In the case of growing mushrooms on a substrate with hydrochloric acid-pretreated sawdust fruit bodies of the second wave had 1.3 times higher protein content and 1.7 times higher polysaccharide content than fruit bodies of the first wave. Thus, a comparative study of different pretreatments of lignocellulosic materials revealed a high efficiency of hydrochloric acid pretreatment step in preparing pine sawdust substrates for cultivation of $H$. erinaceus.

Keywords: basidiomycetes, Hericium erinaceus, Ganoderma lucidum, Flammulina velutipes, solid-phase cultivation, substrate, pine sawdust, beech sawdust, pretreatment. 